\title{
ANALISIS TEKNO-EKONOMI PELUANG PEMBANGUNAN INDUSTRI PENGOLAHAN SPECIALTY NATURAL RUBBER JENIS KARET ALAM TERHIDROGENASI
}

\author{
Techno-economic Analysis of the Opportunity Development Specialty Natural Rubber Industry Based on \\ Hydrogenated Natural Rubber
}

\author{
Santi Puspitasari, Asron Ferdian Falaah, dan Adi Cifriadi \\ Pusat Penelitian Karet, Jalan Salak Nomor 1 Bogor 16151 Jawa Barat \\ Email : puspitasari.santi@puslitkaret.co.id
}

Diterima 5 Desember 2017 / Direvisi 8 Februari 2018 / Disetujui 28 Februari 2018

\begin{abstract}
Abstrak
Konsep Green Polymer telah menjadi perhatian bagi para pelaku industri polimer yang dibuktikan dengan dikembangkannya berbagai tipe Specialty Natural Rubber. Salah satunya adalah karet alam terhidrogenasi (HNR). HNR memiliki keunggulan berupa ketahanan terhadap proses oksidasi termal sehingga diharapkan dapat mensubstitusi karet sintetik berbasis petroleum (EPDM, CR, dan IRR). Pusat Penelitian Karet telah berhasil memperoleh teknologi pengolahan HNR. Artikel ini mengulas peluang pendirian pabrik pengolahan HNR ditinjau dari aspek teknoekonomi. Metode untuk memperoleh data primer dilakukan dengan cara survei dan wawancara, sedangkan data sekunder diperoleh dengan teknik multiplikasi dokumen dan pencatatan dari lembaga terkait. Data diolah secara deskriptif kualitatif dan kuantitatif. Hasil analisis diketahui bahwa potensi pasar dalam negeri untuk industri HNR cukup terbuka mencapai 18 ribu ton per tahun. Industri HNR direncanakan akan didirikan di Kawasan Industri Kendal, Kendal, Jawa Tengah dengan kapasitas produksi sebesar 3.600 ton per tahun (20\% dari potensi pasar). Penetapan kapasitas produksi turut didukung oleh kemampuan pasok bahan baku lateks pekat sebesar 4.500 ton per tahun. Teknologi proses yang diterapkan untuk memproduksi HNR skala industri akan mengadopsi proses pengolahan karet
\end{abstract}

konvensional jenis crepe. Hasil analisis kelayakan finansial menunjukkan bahwa industri HNR layak untuk didirikan. Industri ini memberikan nilai NPV sebesar IDR 25,3 M, IRR sebesar 18,63\%, B/C ratio sebesar 1,16 dan PBP selama 5,63 tahun. Sementara berdasarkan hasil analisis sensitivitas diketahui bahwa industri ini sangat sensitif terhadap kenaikan nilai tukar USD terhadap IDR dan penurunan harga jual karet alam terhidrogenasi.

Kata kunci : Karet alam; hidrogenasi; tekno ekonomi; analisis finansial

\section{Abstract}

Green polymer concept has become the main concern of the polymer's stakeholders. This reality is shown by the development of various type of Specialty Natural Rubber, including Hydrogenated Natural Rubber (HNR). HNR has superiority on the thermal oxidative resistance property, so it is expected to subtitute petroleum based synthetic rubbers (EPDM, CR and IIR). Indonesian Rubber Research Institute has developed processing technology of HNR. This article reviewed the possibility of HNR processing industry development in the terms of techno-economic aspects. Primary data was obtained by survey and interview techniques, while secondary data was collected by multiplication technique from related institutions. The primary and secondary data were analyzed qualitative and quantitative descriptively. From the 
result of study, it could be understood that local market potencial of HNR reached 18,000 ton per year. HNR industry was planned to be built in Kendal Industrial Park, Kendal, Central Java with capacity as 3,600 ton per year (20\% of market potencial). The determination of capacity was supported by the supply of latex concentrated production as raw material for HNR as 4,500 ton per year. HNR production technology adopted coventional raw natural rubber-crepe grade. Thus, the result of the financial analysis showed that $H N R$ industry was feasible to be developed which indicated by positive NPV (IDR $25.3 \mathrm{M}$ ), IRR as 18.63\%, $B / C$ ratio as 1.16 , and $P B P$ as 5.63 year. The sensitivity analysis of HNR industry was so susceptible to the changes of raise on USD exchange rate and decrease on HNR selling price.

Keywords : Natural rubber; hydrogenation; techno economy; financial analysis

\section{Pendahuluan}

Perkembangan teknologi dan industri polimer di seluruh dunia saat ini telah mulai diarahkan menuju konsep "Green Polymer". Mülhaupt (2013), menyatakan bahwa sejak awal abad ke-19, polimer alam atau biopolimer telah dimodifikasi secara kimiawi untuk mengubah sifat bahan tersebut sehingga memiliki sifat baru yang lebih berdaya guna dengan harapan dapat mensubstitusi polimer sintetik berbasis petroleum. Salah satu implementasi nyata konsep "Green Polymer" adalah dengan dikembangkannya Specialty Natural Rubber. Specialty Natural Rubber adalah karet alam untuk penggunaan khusus yang diperoleh dari hasil modifikasi kimiawi karet alam. Dalam perdagangan, jenis Specialty Natural Rubber yang telah dikomersialkan antaralain:

a. Karet alam epoksidasi dengan merek dagang "Ekoprena". Karet alam modifikasi yang dikembangkan oleh Malaysian Rubber Board ini memiliki keunggulan tahan terhadap minyak dan diharapkan dapat menggantikan karet sintetik NBR.

b. Karet alam deproteinisasi dengan merek dagang "Pureprena", merupakan bentuk
Specialty Natural Rubber yang juga dikembangkan oleh Malaysian Rubber Board. Karet dengan kadar protein rendah ini cocok digunakan sebagai bahan baku dalam pembuatan sarung tangan non alergenik.

c. Polimerisasi cangkok karet alam dengan poli metil metakrilat (NR-g-MMA) dengan merek dagang "Megapoly" dan "Megatex" yang diproduksi oleh Beaufort Specialty Rubber Factory. Karet ini digunakan utamanya sebagai bahan baku perekat.

Pusat Penelitian Karet selaku lembaga litbang yang bergerak dalam bidang perkaretan di Indonesia telah mencoba mengembangkan teknologi pembuatan tipe lain dari Specialty Natural Rubber yang berbeda dengan yang telah dikembangkan oleh Malaysia yaitu karet alam hidrogenasi (Hydrogenated Natural Rubber, HNR). Riset mengenai teknologi HNR yang telah dikembangkan secara intensif sejak tahun 2015, saat ini telah mencapai tahap skala semi pilot (berkapasitas 2,5-10 kg lateks pekat/batch). Artikel ini mengkaji peluang pendirian pabrik pengolahan HNR dari lateks karet alam ditinjau dari aspek tekno-ekonomi. Kajian tekno ekonomi ini dimaksudkan sebagai salah satu dasar dalam penentuan kelayakan pengembangan riset HNR pada tahap yang lebih besar (skala pilot).

\section{Bahan dan Metode}

Analisis tekno-ekonomi dalam kajian ini dilakukan dengan menerapkan beberapa metode untuk mendapatkan data primer dan sekunder. Metode survei untuk memperoleh data primer dilakukan dengan teknik wawancara kepada para responden yang telah dipilih secara sengaja (purposive). Responden yang dipilih meliputi pihak manajemen pengelola kawasan industri, produsen lateks pekat, serta produsen atau supplier bahan kimia. Sementara untuk perolehan data sekunder dilakukan dengan mengaplikasikan teknik multiplikasi dokumen dan pencatatan dari Kantor atau Lembaga Pemerintahan dan Asosiasi terkait. 
Data primer dan sekunder yang telah diperoleh kemudian diolah menggunakan analisis deskriptif kualitatif dan kuantitatif. Analisis deskriptif kualitatif mencangkup potensi pasar, potensi lokasi pendirian pabrik, serta teknologi produksi. Sementara analisis kuantitatif dilakukan melalui pendekatan kelayakan finansial dengan empat kriteria investasi proyek yaitu Nett Present Value (NPV), Internal Rate of Return (IRR), Benefit Cost Ratio (B/C Ratio), dan Payback Period (PBP). Analisis sensitivitas turut dikaji dalam analisis kuantitatif dengan menerapkan variabel yang mempengaruhi kelayakan finansialnya.

\section{Hasil dan Pembahasan}

\section{Karet Alam Terhidrogenasi (Hydrogenated Natural Rubber)}

Karet alam terhidrogenasi (Hydrogenated natural rubber, HNR) merupakan salah satu bentuk karet khusus yang diharapkan dapat menggantikan fungsi karet sintetik dengan keunggulan ketahanan terhadap cuaca dan oksidasi termal. Secara kimiawi, HNR memiliki struktur molekul menyerupai karet sintetik jenis etilena propilena diena monomer (EPDM) (Piya-areetham et al., 2013b; Pruttisirikul et al., 2010; Inoue \& Nishio, 2007). HNR tersusun atas rantai panjang hidrokarbon cis 1,4-poliisoprena dengan kandungan ikatan rangkap tak jenuh $\mathrm{C}=\mathrm{C}$ yang cukup rendah. Reaksi hidrogenasi mengakibatkan terputusnya ikatan rangkap tak jenuh $\mathrm{C}=\mathrm{C}$ yang bersifat sangat reaktif terhadap oksidasi termal menjadi ikatan tunggal jenuh C-C yang tahan terhadap paparan oksigen, ozon dan sinar matahari tanpa disertai oleh terputusnya rantai panjang molekul karet alam tersebut (Piya-areetham et al., 2013b; Pruttisirikul et al., 2010; Inoue \& Nishio, 2007). Dengan demikian HNR masih dapat mempertahankan sifat mekanik yang unggul dari karet alam namun menjadi lebih tahan terhadap cuaca dan proses oksidasi termal.

Prosedur dalam pembuatan HNR dari karet alam fase lateks dapat dilakukan secara hidrogenasi konvensional menggunakan gas $\mathrm{H}_{2}$ atau transfer hidrogenasi menggunakan senyawa diimida. Prosedur dengan menerapkan hidrogenasi konvensional telah banyak ditinggal karena metode ini dianggap kurang praktis dan ekonomis. Reaksi hidrogenasi konvensional lateks karet alam dengan gas $\mathrm{H}_{2}$ hanya dapat dijalankan pada suhu dan tekanan tinggi serta berkatalis logam berat. Dengan demikian prosedur ini melibatkan terjadinya difusi transfer massa yang cukup kompleks (Tangthongkul et al., 2005; Wang \& Astruc, 2015). Sedangkan pada reaksi transfer hidrogenasi, konversi lateks karet alam menjadi HNR oleh senyawa donor hidrogen dapat dilakukan pada suhu di bawah $70^{\circ} \mathrm{C}$ dan tekanan atmosfer, serta menggunakan katalis homogen. Senyawa donor hidrogen yang paling umum digunakan secara insitu dalam reaksi transfer hidrogenasi adalah senyawa diimida. Senyawa diimida dapat diperoleh melalui berbagai metode antara lain oksidasi hidrasin hidrat oleh hidrogen peroksida, dekarboksilasi pottasium azodicarboksilat, dan dekomposisi termal $p$ toluenesulfonylhydrazide (Samran et al., 2005; Mahittikul et al., 2007). Reaksi transfer hidrogenasi dengan senyawa diimida mengikuti mekanisme reaksi yang dikembangkan oleh Lin et al. (2004) sebagai berikut:

$$
\begin{gathered}
\mathrm{N}_{2} \mathrm{H}_{4}+\mathrm{H}_{2} \mathrm{O}_{2} \rightarrow \mathrm{N}_{2} \mathrm{H}_{2}+2 \mathrm{H}_{2} \mathrm{O} \\
\mathrm{N}_{2} \mathrm{H}_{2}+-\mathrm{HC}=\mathrm{CH}-\rightarrow \mathrm{N}_{2}+-\mathrm{H}_{2} \mathrm{C}-\mathrm{CH}_{2}-
\end{gathered}
$$

Secara fisik, lembaran HNR yang layak untuk dikomersialkan dicirikan berwarna cokelat, bertekstur kokoh, kuat, tidak lengket, dan tidak lembek/lunak sebagaimana diilustrasikan pada Gambar 1 sebagai berikut. Ciri fisik tersebut menandakan bahwa HNR masih tersusun oleh rantai panjang cis 1,4poliisoprena(Cifriadi et al., 2017).

\section{Potensi Pasar}

Produksi HNR dimaksudkan untuk mensubstitusi karet sintetik yang umumnya digunakan dalam pembuatan produk karet 


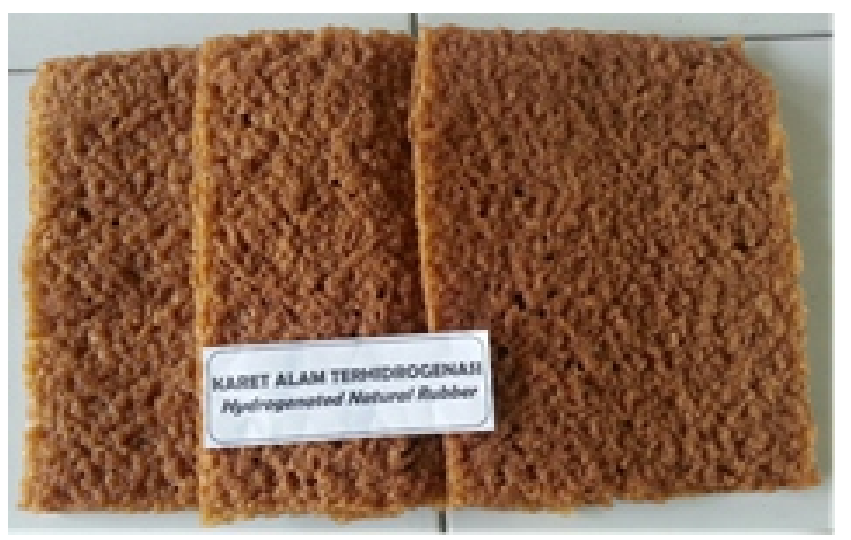

Gambar 1. Ciri fisik lembaran karet alam terhidrogenasi

untuk aplikasi luar ruangan (outdoor rubber based product). Produk karet yang termasuk golongan tersebut antara lain selang karet, conveyor belt, dan barang jadi karet lainnya. Barang jadi karet lainnya saat ini banyak diimplementasikan untuk mendukung pembangunan infrastruktur misalnya aspal karet, karet bantalan dermaga (dock fender), karet bantalan untuk bangunan tahan gempa (seismic bearing), karet bantalan rel kereta api (rail pad) dan karet bantalan untuk perletakan jembatan dan jalan layang (elastomer bridge bearing, EBB). Berdasarkan data neraca perdagangan (Gambar 2) terlihat bahwa barang jadi karet untuk aplikasi luar ruangan memiliki neraca perdagangan bernilai negatif yang cukup tajam. Hal ini berarti bahwa kuantitas impor produk tersebut lebih besar daripada ekspor. Pemenuhan kebutuhan barang karet untuk aplikasi luar ruangan sebagian besar harus dilakukan secara impor karena dalam manufakturnya memerlukan karet yang memiliki keunggulan terhadap cuaca dan proses oksidasi termal (paparan oksigen, ozon, dan sinar matahari). Jenis karet ini tidak dapat dipenuhi oleh karet alam, melainkan harus menggunakan karet sintetik jenis EPDM, Butil(IIR) dan CR.

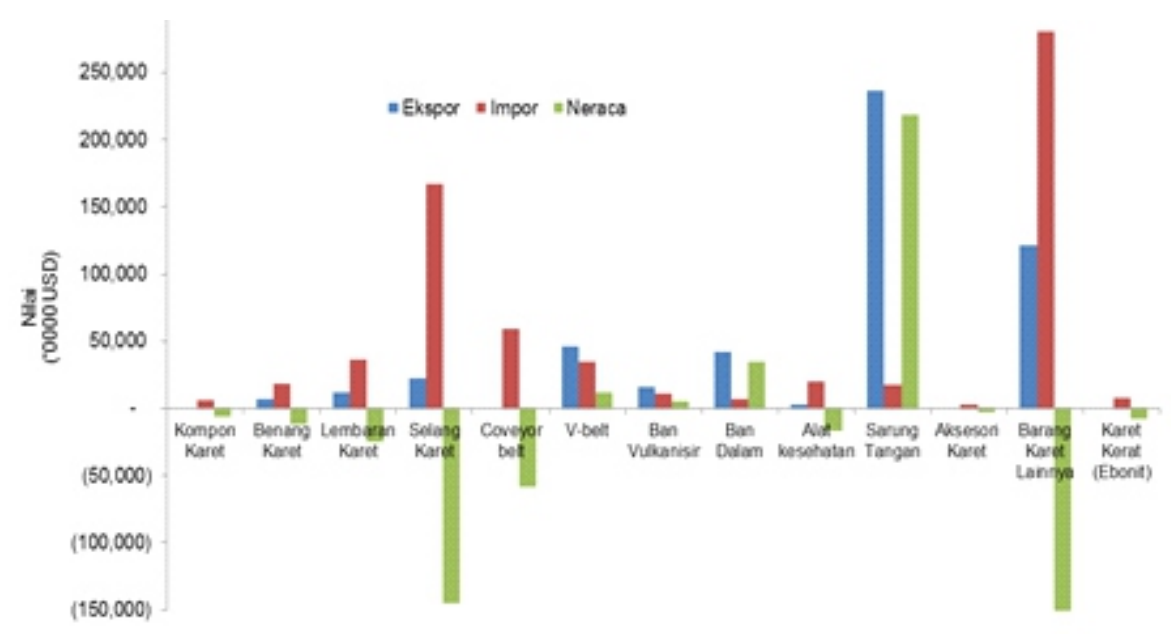

Sumber: Badan Pusat Statistik, 2015

Gambar 2. Neraca perdagangan barang jadi karet Indonesia, 2014 
Tabel 1. Perkembangan impor karet sintetik, periode 2013 - 2016

\begin{tabular}{lcccc}
\hline \multirow{2}{*}{ Tipe karet sintetik } & \multicolumn{4}{c}{ Volume impor (Ton) } \\
\cline { 2 - 5 } & 2013 & 2014 & 2015 & 2016 \\
\hline Karet butil (IIR) & 12.534 & 12.519 & 11.557 & 15.740 \\
Lateks kloroprena (CR) & 2570 & 5060 & 4811 & 4928 \\
Karet kloroprena (CR) & 5574 & 5515 & 6286 & 6024 \\
Karet EPDM & 10.802 & 11.158 & 10.164 & 12.045 \\
\multicolumn{1}{c}{ Jumlah } & 31.480 & 34.252 & 32.818 & 38.737 \\
\hline
\end{tabular}

Tabel 1 menginformasikan volume impor karet sintetik dengan spesifikasi tahan oksidasi termal dan cuaca. Data volume impor karet sintetik digunakan sebagai acuan dalam menentukan potensi pasar karet alam terhidrogenasi. Dari Tabel 1 terlihat bahwa potensi pasar karet sintetik yang memiliki keunggulan ketahanan oksidasi termal cukup besar, dalam empat tahun terakhir rata-rata mencapai 34 ribu ton. Dalam kajian ini, potensi pasar yang diharapkan dapat direbut oleh HNR hanya pasar karet CR dan EPDM sebesar 18 ribu ton. Karet CR digunakan untuk memproduksi karet bantalan jembatan dan jalan layang komersial sedangkan karet EPDM umumnya untuk memproduksi rubber roofing, rubberflooring, dan rubber hose.

\section{Kemampuan Pasok Bahan Baku}

Kemampuan pasokan lateks karet alam pekat sebagai bahan baku dalam produksi karet alam terhidrogenasi dapat diketahui dari kondisi terkini kinerja agroindustri karet nasional. Komoditas karet saat ini diusahakan oleh perkebunan besar negara (BUMN), swasta dan rakyat (petani karet). Dalam pengolahan hasil kebun, petani karet cenderung menghasilkan bahan olah karet dalam bentuk lump mangkok dan sleb yang mutunya relatif kurang baik dan akan digunakan sebagai bahan baku pengolahan karet remah SIR 20. Sementara itu, secara umum perkebunan besar baik negara maupun swasta telah menerapkan teknologi budidaya karet sesuai rekomendasi, mulai dari pemilihan klon, jarak tanam, pemupukan, dan pengendalian hama penyakit sehingga dapat menghasilkan bahan olah karet yang mutunya jauh lebih baik dibandingkan petani karet. Bahan olah karet yang diproduksi oleh perkebunan besar antara lain lateks kebun dan lump serta slab berkualitas baik. Lateks kebun ini selanjutnya akan diolah menjadi lateks pekat.

Sebagian besar produksi karet alam Indonesia menjadi komoditas ekspor dengan proporsi mencapai $85 \%$ dari total produksi nasional. Karet alam Indonesia diekspor dalam berbagai jenis, yaitu lateks pekat, RSS dan SIR. Jumlah dan nilai ekspor karet alam Indonesia berdasarkan jenis mutunya disajikan pada Tabel 2. Tampak pula bahwa setiap tahunnya ekspor karet alam sangat didominasi oleh jenis SIR 10/20, terutama SIR 20 yang mencapai 97\%. Sisanya diekspor dalam jenis karet RSS dan lateks pekat. Volume ekspor lateks pekat mencapai 5.400

Tabel 2. Jumlah dan nilai ekspor karet alam Indonesia berdasarkan jenis mutu

\begin{tabular}{|c|c|c|c|c|}
\hline \multirow{2}{*}{ Jenis mutu } & \multicolumn{4}{|c|}{ Tahun } \\
\hline & 2011 & 2012 & 2013 & 2014 \\
\hline Lateks pekat & 9,5 & 7,6 & 5,9 & 5,4 \\
\hline Karet sit asap (RSS) & 67,3 & 66,7 & 69,3 & 68,3 \\
\hline Karet remah (SIR 10/20) & 2478,9 & $2-370,1$ & 2625,1 & $2.549,7$ \\
\hline Mutu lainnya & - & - & 1,6 & 0,02 \\
\hline Jumlah (ribu ton) & $2-555,7$ & $2-444,4$ & $2-702,0$ & $2-673,5$ \\
\hline
\end{tabular}


ton di tahun 2014. Jumlah ini masih mencukupi apabila diserap di dalam negeri untuk memenuhi kebutuhan dalam produksi karet alam terhidrogenasi. Salah satu pabrik penghasil lateks pekat di Indonesia adalah Kebun Merbuh PT. Perkebunan Nusantara IX yang berlokasi di Kabupaten Kendal Provinsi Jawa Tengah. Selanjutnya untuk bahan baku berupa hidrasin hidrat direncanakan akan dipasok oleh supplier PT. Insoclay Acidatama Indonesia yang berlokasi di Cikarang, Jawa Barat, sedangkan hidrogen peroksida akan disediakan oleh PT. Samator Inti Peroksida yang berlokasi di Gresik, Jawa Timur.

\section{Pemilihan Rencana Lokasi Pendirian Pabrik}

Industri pegolahan HNR direncanakan akan didirikan di Kawasan Industri Kendal (Kendal Industrial Park) yang berlokasi di Kabupaten Kendal, Provinsi Jawa Tengah. Denah Kawasan Industri Kendal disajikan pada Gambar 3.

Pemilihan calon lokasi pendirian pabrik HNR didasarkan pertimbangan berikut : a. Kedekatan dengan letak pemasok sumber bahan baku utama

Sumber bahan baku utama yang digunakan dalam produksi HNR adalah lateks karet alam pekat yang dihasilkan oleh Kebun Merbuh PT. Perkebunan Nusantara IX. Kebun Merbuh berlokasi di Kabupaten Kendal dan berjarak sekitar 20 KM dari Kawasan Industri Kendal. Lokasi yang saling berdekatan akan meminimalisasi risiko kerusakan sistem kestabilan koloid lateks pekat. Sistem kestabilan koloid lateks karet alam sangat sensitif terhadap goncangan dan panas yang mungkin timbul selama pengangkutan. Apabila kestabilan lateks telah rusak dan lateks mengalami penggumpalan maka tidak dapat diproses menjadi HNR. Untuk kebutuhan bahan baku lain berupa hidrasin hidrat $80 \%$ dipasok dari PT. Insoclay Acidatama Indonesia berlokasi di Kabupaten Cikarang, Jawa Barat dan hidrogen peroksida 30\% dipasok dari PT. Samator Inti Peroksida di Kabupaten Gresik, Jawa Timur. Calon lokasi

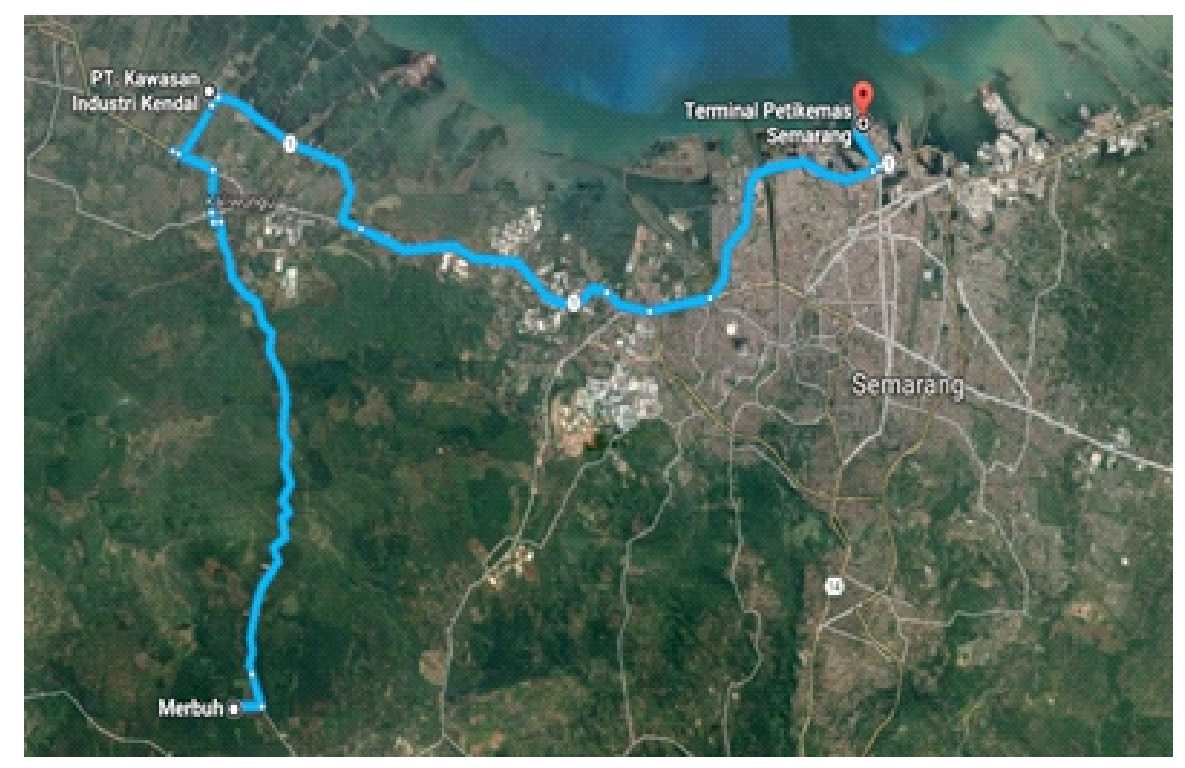

Gambar 3. Kawasan Industri Kendal, Kabupaten Kendal, Jawa Tengah 
pabrik HNR yang dipilih berada di Kawasan Industri Kendal dianggap tepat karena berada sangat dekat dengan pabrik lateks pekat dan berada relatif di tengah antara pabrik hidrasin hidrat dan hidrogen peroksida.

b. Akses transportasi, pengangkutan dan pemasaran produk

Kawasan Industri Kendal didukung oleh aksesibilitas yang mudah dijangkau. Kawasan Industri Kendal terletak diantara pusat industri utama di Pulau Jawa yaitu Jakarta, Surabaya, dan Bandung. Kawasan industri ini berada pada jarak hanya sekitar 7 KM dari Pelabuhan Kendal dan sekitar $30 \mathrm{KM}$ dari Terminal Peti Kemas Semarang. Lokasi yang berdekatan dengan pelabuhan akan mempermudah pemasaran HNR. Untuk kepentingan bisnis, lokasi Kawasan Industri Kendal dianggap cukup strategis mengingat lokasinya yang berdekatan dengan ibu kota Provinsi Jawa Tengah di Kota Semarang (sekitar 26 KM) sebagai salah satu sentra pemerintahan dan bisnis di Pulau Jawa. Lokasi ini memberikan efisiensi dalam perizinan usaha karena terdapatnya Badan Koordinasi Penanaman Modal Jawa Tengah di Kota Semarang. Transportasi menuju Kawasan Industri Kendal dapat diakses melalui jalur darat, baik dengan kendaraan kecil maupun berat karena tersedianya akses jalan nasional (Jalur Pantura) dengan kondisi yang cukup baik. Untuk menuju Terminal Peti Kemas Semarang dapat melalui akses tol.

c. Ketersediaan sumber energi, utilitas dan infrastruktur pendukung lain

Kawasan Industri Kendal menawarkan lingkungan industri yang lengkap dengan dukungan sumber energi dan utilitas serta infrastruktur pendukung berstandar internasional. Kawasan Industri Kendal Tahap 1 seluas $860 \mathrm{Ha}$ (total luas pengembangan mencapai $2.700 \mathrm{Ha}$ ) didukung oleh kapasitas sumber listrik sebesar $660 \mathrm{MW}$, air bersih sebesar $24.000 \mathrm{~m}^{3} /$ hari, dan pengelolaan air limbah sebesar 20.000 $\mathrm{m}^{3} /$ hari. Di masa mendatang kawasan industri ini menawarkan bidang tanah (kavling siap bangun) maupun pabrik siap pakai serta zona komersial dan hunian.

d. Ketersediaan tenaga kerja

Kawasan Industri Kendal yang berada di Kabupaten Kendal Provinsi Jawa Tengah didukung oleh potesi tenaga kerja terampil yang berasal dari Kabupaten Kendal dan kotakota disekitarnya. Di Provinsi Jawa Tengah terdapat 1.184 lembaga pelatihan kerja, 274 Universitas, dan 20 Politeknik sebagai sarana penghasil sumber daya manusia yang unggul dan terampil. Selain itu, dengan tingkat upah yang relatif masih rendah dibandingkan dengan daerah sentra industri lain di Indonesia maka mampu menyediakan tenaga kerja yang kompetitif bagi investor. Pada tahun 2017, UMK di Kabupaten Kendal sebesar IDR 1.774.867 (sekitar USD 132).

\section{Struktur Organisasi Pabrik}

Struktur organisasi pabrik karet alam terhidrogenasi dirancang sesuai dengan ilustrasi dalam Gambar 4. Pabrik akan dipimpin oleh seorang Direktur yang dalam menjalankan tugasnya dibantu oleh dua orang manajer yaitu Manajer Umum \& SDM serta Manajer Produksi \& Teknik. Selanjutnya Manajer Umum \& SDM akan membidangi Bagian Logistik (Pengadaan Bahan Baku \& Pemasaran) dan Tata Usaha (Keuangan \& Personalia). Sedangkan lingkup kerja Manajer Produksi dan Teknik mencakup Bagian Produksi (Reaksi), Bagian Pengolahan (Proses Basah, Proses Kering), Bagian Teknik (Pemeliharaan Mesin dan Peralatan), Pengendalian Mutu (QC), dan IPAL. Karyawan Pelaksana atau Teknisi yang berstatus pegawai tetap yang direncanakan akan dipekerjakan dalam pabrik ini sebanyak 5 orang. Untuk karyawan penunjang (Security dan Driver) sebanyak 6 orang. Dengan demikian karyawan yang berstatus pegawai tetap sebanyak 21 orang. Untuk memperlancar proses produksi karet alam terhidrogenasi, pihak manajemen pabrik akan merekrut operator berstatus outsourcing sebanyak 15 


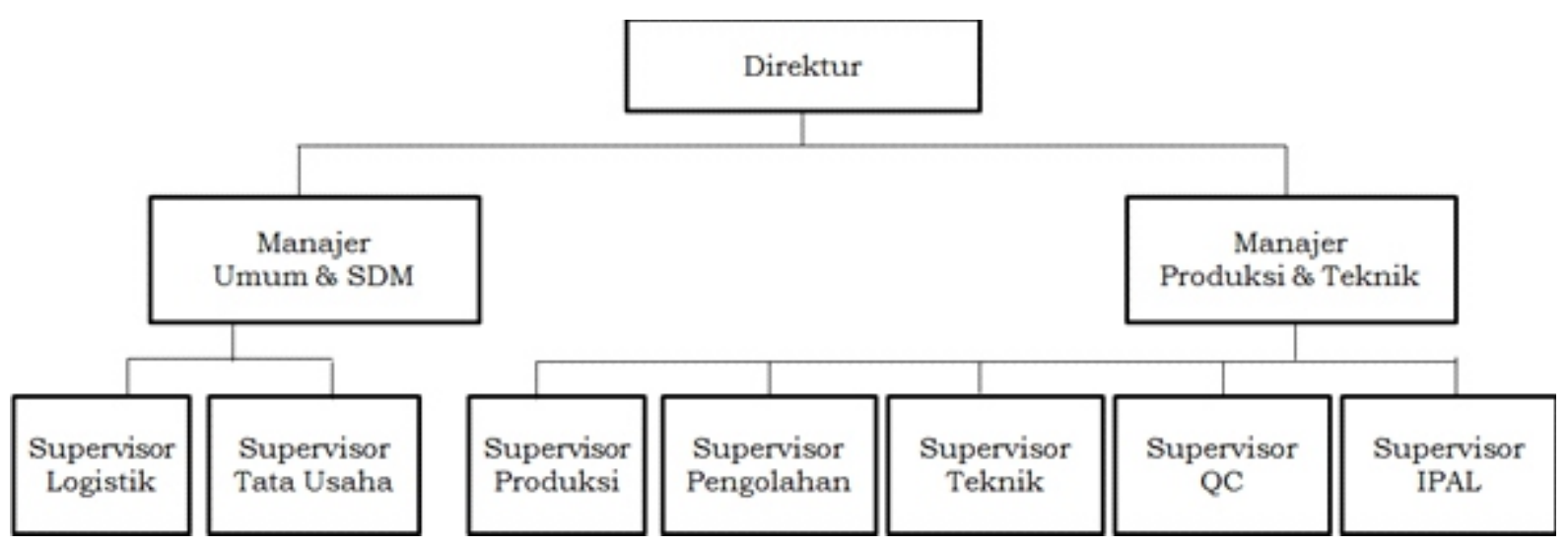

Gambar 4. Struktur organisasi pabrik karet alam terhidrogenasi

orang. Sehingga seluruh karyawan pabrik berjumlah 36 orang.

\section{Penentuan Kapasitas Produksi}

Kapasitas produksi pabrik HNR yang diperhitungkan dalam kajian tekno-ekonomi ini hanya dirancang untuk dapat memenuhi sekitar 20\% dari potensi pasar yang masih terbuka atau setara dengan 3.600 ton per tahun. Kapasitas produksi terpasang tersebut ditetapkan dengan mengambil pertimbangan bahwa industri pengolahan HNR merupakan industri baru di Indonesia bahkan di dunia. Industri pengolahan karet khusus (specialty rubber) hasil modifikasi karet alam jumlahnya masih sangat terbatas di dunia. Dengan demikian, industri HNR dapat dikatakan sebagai pemain baru dalam industri karet alam mentah yang akan bersaing dengan produsen karet sintetik CR dan EPDM eksisting yang telah mapan dan memiliki target pasar nyata. Untuk itu strategi yang digunakan untuk merebut pangsa pasar oleh industri baru ini dilakukan secara bertahap dengan memasang kapasitas produksi awal sebesar $20 \%$ dari potensi pasar yang masih terbuka terutama untuk pasar domestik. Kapasitas produksi tersebut juga mempertimbangkan kemampuan pasokan sumber lateks karet alam pekat dari Kebun Merbuh PT. Perkebunan Nusantara IX. Kebun Merbuh mampu memproduksi lateks pekat sebesar 4.500 ton pertahun.

\section{Teknologi Proses Produksi}

Kondisi reaksi dalam pembuatan HNR ditetapkan berdasarkan hasil percobaan yang diperoleh melalui kegiatan riset pada skala semi pilot, sedangkan proses pengolahan HNR mengacu pada SOP produksi karet konvensional jenis krep (crepe). Prosedur ini dipilih karena dianggap hanya memerlukan biaya investasi yang rendah. Diagram alir proses pengolahan HNR skala produksi diilustrasikan pada Gambar 5. Dari Gambar 5 dapat dijelaskan bahwa prosedur pengolahan HNR mengikuti alur berikut :

Lateks karet alam pekat dialirkan dari tangki penyimpanan lateks pekat menuju reaktor hidrogenasi menggunakan pompa diapragma. Lateks pekat dalam reaktor ditambah dengan basa kuat sebagai bahan penstabil dan katalis asam borat. Suhu campuran lateks, basa kuat dan katalis dalam reaktor kemudian dinaikkan hingga mencapai suhu reaksi $50^{\circ} \mathrm{C}$. Pada saat tercapai suhu reaksi, 42,5 phr hidrasin hidrat dan $35 \mathrm{phr}$ hidrogen peroksida dialirkan dan ditambahkan ke dalam campuran lateks pekat dan katalis secara perlahan. Reaksi hidrogenasi lateks pekat menggunakan senyawa diimida yang dihasilkan dari oksidasi hidrasin hidrat oleh hidrogen peroksida dijalankan secara semi batch selama 6 jam pada suhu $50^{\circ} \mathrm{C}$ (non adiabatis - non isotermal) dalam reaktor tangki berpengaduk. Satu jam terakhir (pada reaksi jam ke-5), ke dalam 


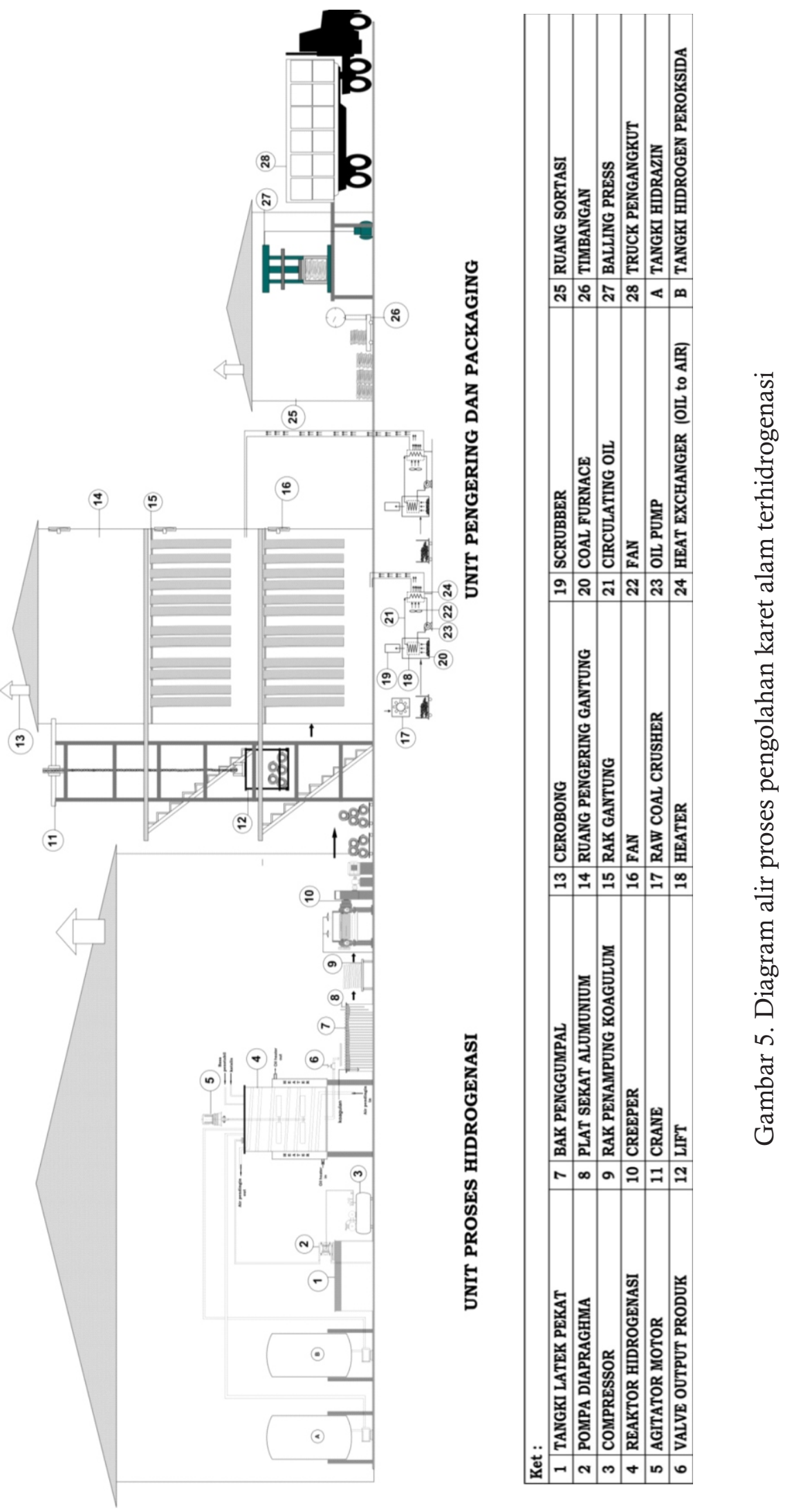


reaktor dialirkan larutan Na-Thiosulfat untuk menetralkan sisa hidrogen peroksida yang tidak bereaksi. Lateks karet alam terhidrogenasi kemudian dikeluarkan dari reaktor dan dialirkan menuju bak penggumpal. Di dalam bak penggumpal, lateks karet alam terhidrogenasi ditambah dengan bahan penggumpal. Koagulum karet alam terhidrogenasi (HNR) yang telah terbentuk kemudian dikeluarkan dari tangki koagulasi. Koagulum HNR kemudian digiling dengan mesin creper sehingga membentuk lembaran (crepe) HNR. Lembaran HNR kemudian disusun di dalam ruang pengering. Pengeringan HNR dilakukan pada suhu $60^{\circ} \mathrm{C}$ selama 4 hari. HNR kering dikeluarkan dari ruang pengering dan dibawa menuju ruang sortasi dan pengemasan.

\section{Kebutuhan Bahan dan Alat - Mesin Produksi Utama}

Rincian kebutuhan bahan dan alat serta mesin utama yang diperlukan untuk memproduksi HNR disajikan dalam Tabel 3 dan Tabel 4. Sebagian besar bahan baku dan mesin pengolahan HNR dipasok dari berbagai produsen di dalam negeri (lokal) sehingga dapat menghemat biaya pengangkutan sertainstalasi mesin dan alat produksi tersebut. Peralatan produksi HNR yang mengadopsi pengolahan karet konvensional dianggap lebih sederhana dibanding dengan mesin dan alat produksi karet remah SIR 20. Mesin utama yaitu reaktor hidrogenasi yang dioperasikan pada kondisi yang cukup aman yaitu pada suhu $50^{\circ} \mathrm{C}$ dan tekanan atmosferis memberikan dampak positif bahwa rancang bangun atau perakitan dan instalasi alat tersebut dalam dilakukan oleh workshop di dalam negeri, meskipun bahan konstruksi yang digunakan tetap perlu didatangkan dari luar negeri.

Tabel 3. Bahan baku dan pendukung pengolahan HNR

\begin{tabular}{|c|c|c|c|c|}
\hline \multirow{2}{*}{ No } & \multirow{2}{*}{ Bahan } & \multicolumn{2}{|c|}{ Sumber } & \multirow{2}{*}{ Fungsi } \\
\hline & & Lokal & Impor & \\
\hline 1 & Lateks karet alam pekat & $\sqrt{ }$ & & Base elastomer \\
\hline 2 & Hidrasin hidrat $80 \%$ & & $\sqrt{ }$ & Sumber senyawa diimida \\
\hline 3 & Hidrogen peroksida $30 \%$ & $\sqrt{ }$ & & Sumber senyawa diimida \\
\hline 4 & Asam borat & & $\sqrt{ }$ & Katalis \\
\hline 5 & Basa kuat $(\mathrm{NaOH})$ & $\sqrt{ }$ & & Penstabil sistem koloid lateks \\
\hline 6 & Natrium thiosulfat & $\sqrt{ }$ & & Penetral sisa hidrogen peroksida \\
\hline 7 & Asam format & $\sqrt{ }$ & & Penggumpal \\
\hline 8 & Solar & $\sqrt{ }$ & & Bahan bakar \\
\hline 9 & Plastik & $\sqrt{ }$ & & Bahan pengemas \\
\hline
\end{tabular}

Tabel 4. Alat dan mesin produksi pengolahan karet alam terhidrogenasi

\begin{tabular}{|c|c|c|c|c|}
\hline \multirow{2}{*}{ No } & \multirow[b]{2}{*}{ Alat } & \multicolumn{2}{|c|}{ Sumber } & \multirow{2}{*}{ Fungsi } \\
\hline & & Lokal & Impor & \\
\hline 1 & Tangki bahan baku & & $\sqrt{ }$ & Tempat penyimpanan bahan baku \\
\hline 2 & Reaktor hidrogenasi & & $\sqrt{ }$ & Reaksi pembentukan karet hidrogenasi \\
\hline 3 & Bak penggumpal & $\sqrt{ }$ & & Tempat penggumpalan karet \\
\hline 4 & Mesin giling creper & $\sqrt{ }$ & & Tempat penggilingan karet hidrogenasi \\
\hline 5 & Dryer & & $\sqrt{ }$ & Tempat pengeringan karet hidrogenasi \\
\hline 6 & Timbangan & $\sqrt{ }$ & & Pengukur bobot karet hidrogenasi \\
\hline 7 & Mesin bandela & $\sqrt{ }$ & & Pembentuk kemasan karet hidrogenasi \\
\hline
\end{tabular}




\section{Analisis Kelayakan Finansial}

Analisis kelayakan finansial pendirian pabrik pengolahan HNR di Kawasan Industri Kendal, Kabupaten Kendal, Jawa Tengah disusun berdasarkan asumsi sebagai berikut:

1. Analisis finansial dilakukan dalam jangka waktu 10 tahun dengan tahun ke-0 digunakan sebagai tahap persiapan dan pembangunan fisik pabrik.

2. Kapasitas pabrik HNR dirancang sebesar 3.600 ton per tahun atau 12 ton karet alam terhidrogenasi per hari. Pada tahun ke-1 pabrik beroperasi pada kapasitas $60 \%$, tahun ke-2 sebesar $80 \%$, tahun ke-3 dan seterusnya sebesar $100 \%$.

3. Harga bahan baku : lateks pekat : IDR $22.950,-/ \mathrm{kg}$; hidrogen peroksida $30 \%$ : IDR $20.250 / \mathrm{kg}$ dan hidrasin hidrat $80 \%$ : IDR $81.000,-/ \mathrm{kg}$

4. Harga pokok penjualan karet alam terhidrogenasi (HNR) : IDR 66.000,-/ kg (90\% harga karet sintetik EPDM)

5. Nilai tukar IDR terhadap USD sebesar USD 1 = IDR 13.500,-

6. Dalam satu tahun ditetapkan sebanyak 300 hari kerja efektif dan setiap hari digunakan satu shift selama 8 jam kerja.

7. Biaya penyusutan dihitung dengan metode garis lurus yang disesuaikan dengan umur ekonomis setiap modal tetap. Umur ekonomis bangunan adalah 20 tahun, mesin dan peralatan 10 tahun, dan kendaraan 5 tahun.

8. Biaya pemeliharaan dihitung sebesar $1 \%$ dari nilai sisa aset untuk bangunan, $2 \%$ mesin dan alat, 1,5\% instalasi pendukung, $2 \%$ alat tulis kantor, dan $3 \%$ kendaraan

9. Biaya asuransi ditetapkan $0,5 \%$ dari nilai setiap aset pada tahun berjalan

10. Debt equity ratio sebesar $70: 30$ yaitu $70 \%$ modal pinjaman dan $30 \%$ modal sendiri.

11.Tingkat suku bunga pinjaman sebesar $10,5 \%$ dan faktor diskonto sebesar $14 \%$

12.Pajak penghasilan dihitung berdasarkan UU Nomor 36 Tahun 2008.
Dalam analisis kelayakan finansial, komponen ekonomi yang diperhitungkan antara lain biaya investasi dan modal kerja, sumber pendanaan, dan biaya operasional. Biaya investasi meliputi biaya yang diperlukan untuk pengadaan mesin dan peralatan, tanah dan bangunan, instalasi penunjang, dan biaya overhead. Besar biaya investasi yang diperlukan untuk pendirian pabrik HNR pada kapasitas 3.600 ton per tahun sebesar IDR 106,4 M. Biaya investasi ini bersumber dari pinjaman bank (70\%) sebesar IDR 74,5 M dan modal sendiri (30\%) sebesar IDR 31,9 M. Selanjutnya pada saat pendirian pabrik diperlukan modal kerja awal sebesar IDR 23,8 M untuk pengadaan bahan baku (IDR 22,7 M) dan biaya operasional (IDR 1,1 M) selama 3 bulan pertama produksi berjalan. Laporan rugi laba memberikan informasi mengenai ringkasan penerimaan dan pembiayaan perusahaan setiap periode akuntansi dan memberikan suatu gambaran kegiatan industri dari waktu ke waktu. Akumulasi pendapatan selama umur ekonomis (10 tahun) adalah sebesar IDR 216,7 M sedangkan total biaya operasi sebesar IDR 167,9 M. Di dalam laporan rugi laba dihasilkan nilai akumulasi laba bersih yang merupakan pendapatan dikurangi biaya operasi, bunga modal pinjaman dan pajak penghasilan. Berdasarkan perhitungan, pada akhir periode kajian akumulasi laba bersih yang dihasilkan adalah IDR 48,7 M.

Proyeksi arus kas terdiri atas komponen kas masuk dan kas keluar. Kas masuk mencakup unsur investasi dan modal kerja, bunga masa konstruksi, laba bersih dan penyusutan. Sementara kas keluar terdiri atas pembiayaan investasi dan modal kerja serta pembayaran pokok pinjaman. Arus kas bersih merupakan selisih dari kas masuk dan kas keluar setiap periode akuntansi. Akumulasi kas bersih merupakan akumulasi arus kas bersih tiap tahun selama jangka waktu perhitungan analisis finansial dilakukan (10 tahun). Proyeksi arus kas operasional pabrik karet alam terhidrogenasi pada tahun pertama menunjukkan nilai yang positif yaitu sebesar IDR 4,2 M. Pada akhir periode analisis (10 
tahun), total kas akhir sebesar IDR $285 \mathrm{M}$. Ringkasan hasil perhitungan analisis finansial disajikan pada Tabel 5 berikut.

Berdasarkan hasil analisis kelayakan finansial investasi pembangunan pabrik karet alam terhidrogenasi yang dinyatakan dalam empat kategori kelayakan yaitu NPV (Net Present Value), IRR (Internal Rate Of Return), B/C (Benefit Cost Ratio) dan PBP (Pay Back Period) seperti dirangkum dalam Tabel 6, dapat diketahui bahwa industri ini layak beroperasi. Hasil studi analisis kelayakan finansial industri karet alam terhidrogenasi yang dioperasikan pada kapasitas produksi sebesar 3.600 ton per tahun memberikan nilai NPV sebesar IDR 25,3 M (bernilai positif atau lebih besar dari nol), IRR sebesar 18,63\% (lebih besar dari faktor diskonto $14 \%$ ), $\mathrm{B} / \mathrm{C}$ ratio sebesar 1,16 (lebih besar dari 1) dan PBP selama 5,63 tahun (masih dalam jangka waktu kajian finansial).

\section{Analisis Sensitivitas}

Analisis sensitivitas dimaksudkan untuk mengetahui tingkat kelayakan industri karet alam terhidrogenasi apabila terjadi perubahan terhadap variabel-variabel yang berpengaruh terhadap produksi baik secara teknis maupun ekonomis. Pada kajian tekno-ekonomi ini, analisis sensitivitas diperhitungkan berdasarkan beberapa skenario berikut:

1. Kenaikan harga bahan baku lateks pekat, karena harga komoditas seperti karet alam sangat bergantung pada posisi supply and demand pada pasar internasional.

2. Kenaikan harga bahan baku hidrasin hidrat karena merupakan barang impor sehingga harganya sangat riskan berubah.

3. Kenaikan nilai tukar USD terhadap IDR.

4. Penurunan harga jual produk karet alam terhidrogenasi (marjin harga jual terhadap harga karet EPDM).

Grafik hasil perhitungan analisis sensitvitas disajikan pada Gambar 6. Dari Gambar 6 terlihat bahwa industri karet alam terhidrogenasi memiliki tingkat kelayakan investasi yang sangat sensitif terhadap adanya perubahan penurunan harga jual produk dan kenaikan nilai tukar USD terhadap IDR. Sedangkan perubahan terhadap kenaikan harga bahan baku lateks pekat dan hidrasin hidrat tidak terlalu berpengaruh terhadap kelayakan finansial industri tersebut. Kenaikan nilai tukar USD terhadap IDR berpengaruh signifikan karena seluruh basis perhitungan pengadaan bahan baku maupun penjualan produk dalam industri karet alam terhidrogenasi dilakukan dalam mata uang USD.

Tabel 5. Ringkasan hasil analisis finansial

\begin{tabular}{clr}
\hline No. & \multicolumn{1}{c}{ Uraian } & Total periode kajian 10 tahun \\
\hline 1 & Biaya investasi ( IDR) & 106.392 .022 .666 \\
2 & Modal kerja (3 bulan)( IDR) & 23.765 .026 .662 \\
3 & Pendapatan (IDR ) & 216.638 .971 .200 \\
4 & Biaya Operasional ( IDR) & 167.911 .675 .581 \\
5 & Laba bersih (IDR ) & 48.727 .295 .619 \\
6 & Total kas akhir & 285.046 .258 .876 \\
\hline
\end{tabular}

Tabel 6. Kelayakan finansial investasi pabrik karet alam hidrogenasi

\begin{tabular}{lr}
\hline \multicolumn{1}{c}{ Indikator kelayakan } & Nilai \\
\hline Net Present Value - NPV ( IDR) & $25.294 .686 .243,-$ \\
Internal Rate of Return - IRR (\%) & 18,63 \\
Net Benefit Cost Ratio - B/C ratio & 1,16 \\
Payback Period - PBP (Tahun) & 5,63 \\
\hline
\end{tabular}




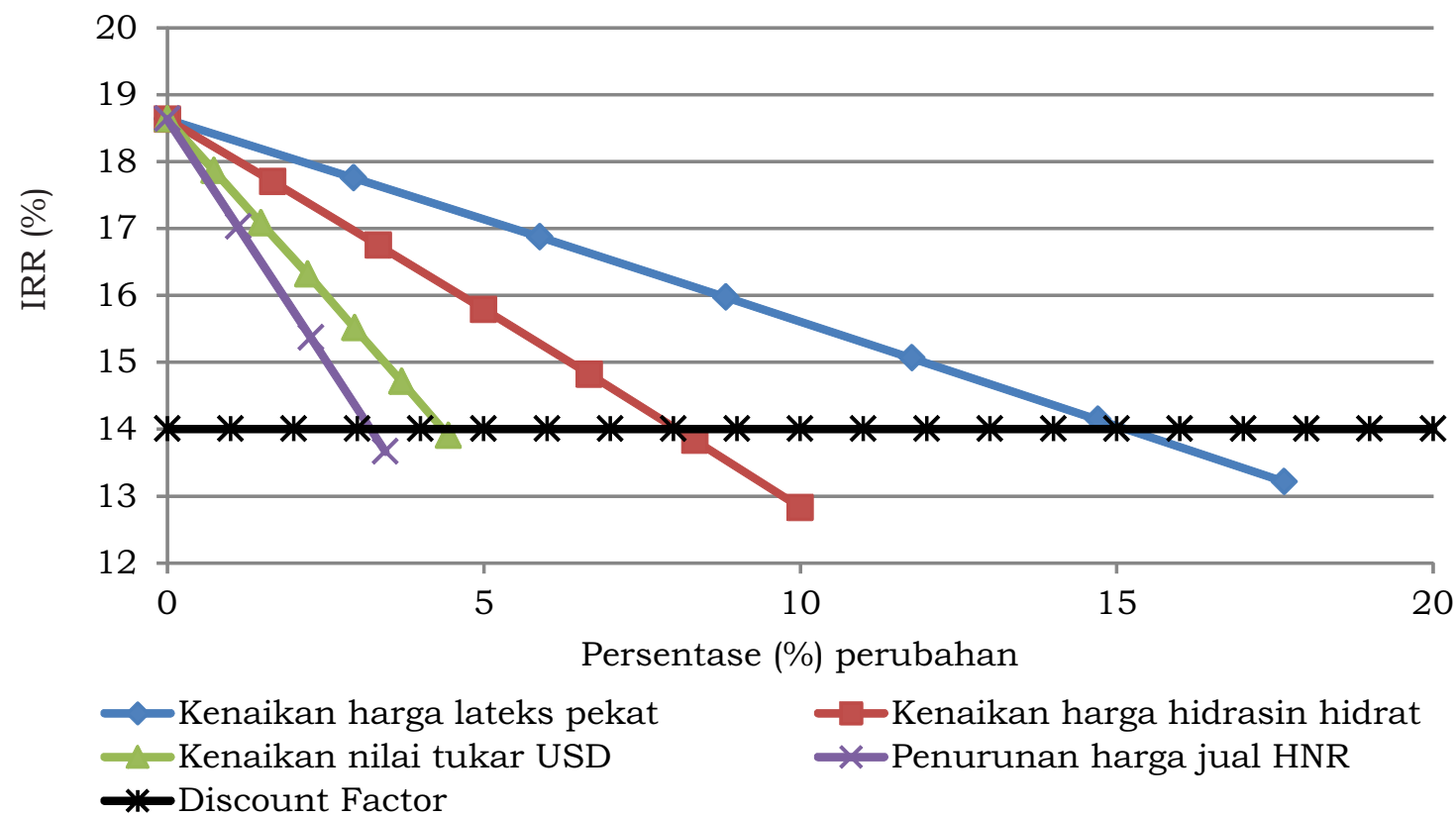

Gambar 6. Analisis sensitivitas industri karet alam terhidrogenasi

\section{Kesimpulan}

Industri karet alam terhidrogenasi merupakan tipe agroindustri baru di Indonesia bahkan di dunia yang bergerak dalam sektor hulu. Industri ini memperkenalkan tipe lain dari karet alam mentah yaitu karet alam dalam bentuk Specialty Natural Rubber yang memiliki keunggulan tahan terhadap proses oksidasi termal, sehingga berpeluang menggantikan fungsi karet sintetik impor jenis EPDM, CR, dan IIR untuk memproduksi produk karet untuk aplikasi luar ruangan. Kajian pendirian industri karet alam terhidrogenasi dengan kapasitas produksi sebesar 3.600 ton per tahun di Kawasan Industri Kendal Jawa Tengah berdasarkan hasil perhitungan analisis finansial dinyatakan layak beroperasi karena memilikiNPV yang bernilai positif, IRR lebih besar dari faktor diskonto, B/C ratio lebih besar dari satu dan PBP masih dalam jangka waktu analisis. Namun mengacu pada hasil analisis sensitivitas adanya perubahan terhadap nilai tukar USD terhadap IDR dan penurunan harga jual produk karet alam terhidrogenasi perlu diwaspadai karena operasional industri ini sangat sensitif terhadap perubahan kedua variabel tersebut.

\section{Ucapan Terima Kasih}

Penulis memberikan penghargaan tinggi dan ucapan terima kasih kepada Kementerian Ristek Teknologi dan Pendidikan Tinggi atas dukungan pendanaan riset melalui program Insentif Sistem Inovasi Nasional (INSINas) Gelombang 2 TA 2017 berdasarkan nomor Kontrak Perjanjian Kerjasama 10/INS2/PPK/E/E4/2017, sehingga kegiatan riset dapat berjalan dengan baik.

\section{Daftar Pustaka}

Badan Pusat Statistik. (2015). Statistik Karet Indonesia. Jakarta, Indonesia: Badan Pusat Statistik.

Cifriadi, A., Chalid, M., \& Puspitasari, S. (2017). Characterization of hydrogenated natural rubber synthesize by diimide transfer hydrogenation. International Journal of Technology, 8(3), 448-457. doi:10.14716/ ijtech.v8i3.1991

Inoue, S. I., \& Nishio, T. (2007). Synthesis and properties of hydrogenated natural rubber. Journal of Applied Polymer Science, 103(6), 3957-3963. doi:10.1002/app.25158 
Lin, X., Pan, Q., \& Rempel, G. L. (2004). Hydrogenation of nitrile-butadiene rubber latex with diimide. Applied Catalysis A: General, 276(1-2), 123-128. doi:10.1016/ j.apcata.2004.07.049

Mahittikul, A., Prasassarakich, P., \& Rempel, G. (2007). Diimide hydrogenation of natural rubber latex. Journal of Applied Polymer Science, 105(3), 1188-1199. doi:10. 1002/app.25944

Mahittikul, A., Prasassarakich, P., \& Rempel, G. L. (2009). Hydrogenation of natural rubber latex in the presence of [Ir (cod)(PCy3)(py)] PF6. Journal of Molecular Catalysis A: Chemical, 297(2), 135-141. doi:10.1016/j.molcata.2008.09.006

Mülhaupt, R. (2013). Green polymer chemistry and bio-based plastics: dreams and reality. Macromolecular Chemistry and Physics, 214(2), 159-174. doi:10.1002/ macp. 201200439

Piya-areetham, P., Prasassarakich, P., \& Rempel, G. L. (2013a). Aqueous-phase hydrogenation of nanosized polyisoprene emulsion using rhodium catalysts. European Polymer Journal, 49(9), 2584-2595. doi:10. 1016/j.eurpolymj.2013.05.025

Piya-areetham, P., Prasassarakich, P., \& Rempel, G. L. (2013b). Organic solvent-free hydrogenation of natural rubber latex and synthetic polyisoprene emulsion catalyzed by water-soluble rhodium complexes. Journal of Molecular Catalysis A: Chemical, 372, 151-159. doi:10.1016/j.molcata .2013 .02 .025
Pruttisirikul, T., Prasassarakich, P., Rempel, G. L., \& Hinchiranan, N. (2010). Thioacetate-and mercapto-functionalized hydrogenated natural rubber. Reactive and Functional Polymers, 70(9), 674-683. doi: 10.1016/j.reactfunctpolym.2010.04.009

Samran, J., Phinyocheep, P., Daniel, P., \& Kittipoom, S. (2005). Hydrogenation of unsaturated rubbers using diimide as a reducing agent. Journal of Applied Polymer Science, 95(1), 16-27. doi:10.1002/ app. 20811

Tangthongkul, R., Prasassarakich, P., \& Rempel, G. L. (2005). Hydrogenation of natural rubber with $\mathrm{Ru}[\mathrm{CH}=\mathrm{CH}(\mathrm{Ph})] \mathrm{Cl}$ (CO)(PCy3) 2 as a catalyst. Journal of Applied Polymer Science, 97(6), 2399-2406. doi:10.1002/app.21922

Wang, D., \& Astruc, D. (2015). The golden age of transfer hydrogenation. Chemical Reviews, 115(13), 6621-6686. doi:10.1021/ acs.chemrev. $5 \mathrm{~b} 00203$ 